\title{
Metoda semiotyczna a procesy kulturowe na pograniczach
}

DOI: 10.19195/2083-7763.8.16

\section{Wstęp}

Celem artykułu jest wykazanie przydatności metody semiotycznej w badaniach procesów kulturowych na pograniczach. Pogranicza rozumiane są tu nie tylko jako obszary położone przy granicach politycznych państw narodowych, lecz przede wszystkim jako pogranicza wytyczone przez procesy kulturowe, które zachodzą między odmiennymi językami, obyczajami, gospodarkami, religiami, ideologiami, prawami. Procesy odbywające się na styku, który możemy nazwać „horyzontem różnicy” ${ }^{1}$, by nie upraszczać ich złożoności, charakteryzują się dynamiką i głębią, przebiegają w porządku synchronicznym i diachronicznym. Pojęcie „horyzont różnicy”, stosowane w ontologii, użyte metaforycznie w tym artykule, wskazuje na złożoną i ukrytą znaczeniowość procesów kulturowych na pograniczach, uzmysłowia nam nieokreśloną bliżej przestrzeń między nieboskłonem a ziemią. Wskazuje na brak możliwości dostrzeżenia linii horyzontu, gdyż ta przesuwa się, gdy się do niej zbliżamy. To, co znajduje się przed horyzontem, jest dla nas dostrzegalne, natomiast wiedza o tym, co jest za linią horyzontu, jest dla nas niedostępna. Horyzont różnicy wskazuje więc na transcendencję, jaka mieści się w badaniach kulturowych najogólniej rozumianych pograniczy.

Siły czy wektory działań społecznych jednostek i grup na pograniczu kulturowym dzięki swojej dynamice zmieniają rzeczywistość. Aby dowiedzieć się, jak te procesy się odbywają, Jurij Łotman sięga do teorii komunikacji, która opiera się na pryncypiach Romana Jakobsona: nadawca $(\mathrm{N})$ - komunikat $(\mathrm{K})$ - odbiorca $(\mathrm{O})$

${ }^{1}$ K. Michalski, Heidegger i filozofia współczesna, Warszawa 1987, s. 31. 
i którą rozszerza o możliwość $\mathrm{N}-\mathrm{K}-\mathrm{N}^{2}$. Ta druga możliwość jest szczególnie istotna, gdyż autointerpretacja komunikatu może dawać nadwyżkę znaczeniową, poszerzoną lub nawet zmienioną interpretację sensu komunikatu. W ten sposób głos badaczy może wzbogacać wiedzę np. o zjawiskach społecznych.

Natomiast $\mathrm{N}-\mathrm{K}$ - O powoduje zupełnie inne zależności i ograniczenia. Nie jest tak, że odbiorca komunikatu rozumie jego sens zgodnie $\mathrm{z}$ intencją nadawcy. Aby zaistniała możliwość pełnego, identycznego zrozumienia sensu komunikatu przez odbiorcę, musiałby on dysponować takimi samymi możliwościami intelektualnymi i taką samą wiedzą oraz kontekstem kulturowym jak nadawca. Jest to sytuacja idealna, ale w rzeczywistości zawsze pojawiają się jakieś zakłócenia, ograniczające pełne odczytanie komunikatu, zgodnie z jego prawdziwym przekazem.

Za przykład może służyć analiza twórczości translatorskiej. Przekład tekstu, czyli komunikatu, z jednego języka na drugi nigdy nie jest dosłowny, a próba przełożenia tekstu tłumaczenia na język oryginału nigdy nie będzie taka sama jak oryginał. To pokazuje także trudności, jakie stoją przed translacją nietekstowych zjawisk kulturowych, powodujących zakłócenia w zrozumieniu komunikacji między zróżnicowanymi społecznościami. Na pograniczach politycznych jest to naturalne zjawisko. Jurij Łotman szczególną uwagę kieruje na rolę tradycji historycznej w rozumieniu komunikatów zorientowanych historycznie ${ }^{3}$. Znajomość historii, czyli niedziedzicznej pamięci historycznej, badanego regionu przygranicznego jest niezbędna, by wyjaśnić współczesne zjawiska społeczne, które są splotem przeszłości i teraźniejszości; zdarza się też, że historia jest ważniejsza od współczesności. Historyk skazany na pracę z tekstem jest deszyfrantem dokumentów. Semiosfera, w której pracuje, ma charakter temporalny, składa się zatem także z dorobku przeszłości, który - czasem ukryty - odradza się, ujawniając historykowi swoje znaczenia. W semiosferze, jako całości kultury, porządek synchroniczny i diachroniczny współistnieją w rozległych przestrzeniach, wpływając na siebie wzajemnie, dlatego historia jest ważną dziedziną nauki, bez której trudno wyjaśniać procesy kulturowe mające miejsce $\mathrm{w}$ semiosferze, $\mathrm{w}$ tym na pograniczach.

Łotman nazywa symbol genem narracji lub też fabuły. Jest to najbardziej trwałe kontinuum kultury ${ }^{4}$. Elementarne symbole, takie jak krzyż, koło, pentagram, stanowią jądro kultury, a treść przez nie wyrażana jest uniwersalnym komunikatem, którego sens jest dostępny każdej jednostce. Dlatego też muzułmanie nazywają chrześcijan krzyżowcami.

Metoda semiotyczna badania tekstów kultury, według Łotmana, opiera się na trzech filarach: teorii komunikacji, niegenetycznej pamięci historycznej i zasobach symboliczno-znakowych danej kultury. Te trzy elementy zostaną wyko-

\footnotetext{
2 J. Łotman, Uniwersum umysłu. Semiotyczna teoria kultury, przeł. B. Żyłko, Gdańsk 2008, s. 79.

3 Ibidem, s. 313.

${ }^{4}$ Ibidem, s. 184.
} 
rzystane w niniejszym artykule do wskazania złożoności zjawisk kulturowych na pograniczach.

Warto uwzględnić też jeszcze szerszą wizję znaczenia komunikacji w społeczeństwie współczesnym, którą znajdujemy w artykule Marceliny Zuber poświęconemu koncepcji komunikacji jako odrębnej dziedziny wiedzy, uwzględniającej następujące aspekty: (i) komunikowanie jako wzajemna orientacja na siebie, wymagająca indywidualnej i zbiorowej interpretacji oraz znajomości kontekstu i symboliki znaczeń; (ii) komunikowanie jako proces społeczny w zglobalizowanym świecie instytucji narodowych i ponadnarodowych, w tym korporacyjnych ${ }^{5}$.

\section{Teoria procesów semiotycznych}

Współczesne definiowanie pojęcia kultury wiąże się z ujęciem komunikacyjnym, a jego podłożem są idee o informacyjnym charakterze świata przyrodniczego i społecznego. Na ogląd informacyjny, będący matrycą obserwowanego przez podmiot świata zewnętrznego, wpłynęły osiągnięcia fizyki i genetyki współczesnej, przyczyniając się do redefinicji pojęcia kultury w jego klasycznym kształcie. $\mathrm{Z}$ tego względu warto zagłębić się $\mathrm{w}$ teorię kulturową wyartykułowaną przez tartusko-moskiewską szkołę, która nadała omawianemu tu pojęciu nową postać. Jej główni twórcy - Jurij Łotman (filolog) i Boris Uspienski (filolog), a także inni uczeni o wielu różnych specjalizacjach - w dyskusjach odbytych $\mathrm{w}$ Tartu na temat roli kultury w życiu społeczeństw uznali, że jest ona najistotniejszym faktem organizującym życie społeczne. Bez kultury niemożliwe jest istnienie społeczeństwa, gdyż „kultura to całokształt informacji niedziedzicznej oraz sposobów jej organizacji i przechowywania"6. Obecnie można uznać te twierdzenia za banalne, ale wnioski, jakie wywiedli z nich badacze, stały się twórczym wkładem do dziedzictwa nauki. Szkoła tartusko-moskiewska, kierując swoje zainteresowania w stronę semiotyki, umocowała kulturę, która jest zbiorowym, ponadindywidualnym intelektem, na podstawach teorii Romana Jakobsona, Ferdinanda de Saussure'a, wykluczając Charlesa Peirce’a, gdyż jego zainteresowania zmierzały w stronę logi$\mathrm{ki}^{7}$. Jakobson, założyciel praskiej szkoły semiotycznej, stworzył podwaliny semiotyki; jest autorem formuły: nadawca - komunikat - odbiorca. Stała się ona podstawą głębokich analiz semiotycznych, doprowadzając do powstania nowatorskiej teorii kultury. Rozpatrywane są w niej, w różnych aspektach, przede wszystkim znaczenia komunikatu, któremu Łotman nadaje hasło „tekstu kultury”. Teksty kultury obejmują nie tylko komunikaty pisane, lecz także inne wytwory materialne i niematerialne myśli ludzkiej w postaci muzyki, malarstwa, architektury,

${ }^{5}$ M. Zuber, Wizja komunikacji jako dyscypliny autonomicznej w koncepcji W. Barnetta Pearce'a, „Prace z Antropologii Komunikacji i Epistemologii Społecznej” 2012, nr 1, s. 209-221.

6 B. Żyłko, Semiotyka kultury Szkoła tartusko-moskiewska, Gdańsk 2009, s. 101.

7 J. Łotman, op. cit., s. 62. 
symboli, znaków, obyczajów, nauki, prawa itp. Podstawą do zaistnienia w świadomości podmiotu komunikatu, czyli tekstu kultury, jest jego sens. Teksty kultury wyrażają się w języku naturalnym, który jest najbardziej rozwiniętym systemem znakowym, najbardziej uniwersalnym środkiem komunikacji. Język naturalny jest wzorem systemowości w kulturze.

Najistotniejszym elementem komunikatu jest sens i znaczenie jego treści, a zatem istotą komunikacji jest zrozumienie i porozumienie między nadawcą a odbiorcą. Nad językiem naturalnym nadbudowane są tzw. wtórne systemy modelujące, czyli języki cząstkowe, obsługujące zorganizowane dziedziny kultury, takie jak prawo, nauka, ideologia itp. Język naturalny i wtórne systemy modelujące zanurzone są w przestrzeni semiosfery, obejmującej całość procesów kulturowych.

Nauka, ale i też religia są nieuchronnie zakorzenione w języku naturalnym. Jest on wspólnym źródłem dla wszystkich wtórnych systemów modelujących. Ale w nauce istotną rolę odgrywa sama badana rzeczywistość. Modele naukowe nie dążą do konstruowania „własnego świata denotatów", lecz do adekwatnego uchwycenia procesów, przebiegających w realnym świecie. Język nauki też można opisywać w terminach przekodowywania $\mathrm{z}$ języka naturalnego, ale celem innowacji terminologicznych (tworzenia terminów-metafor) jest lepsze poznanie tego wycinka rzeczywistości, który stanowi przedmiot danej nauki ${ }^{8}$.

Łotman w Uniwersum umysłu analizuje właściwości semiosfery. Jest ona, jak biosfera, przestrzenią wielowymiarową, ustrukturowaną, umożliwiającą zaistnienie złożonych procesów wymiany informacji. Charakteryzuje się niejednorodnością i asymetrią, dzięki czemu cały system kultury jest dynamiczny, zmienia się nieustannie pod wpływem sił społecznych i innych czynników zwanych nie-kulturą. Nie-kultura to obszar funkcjonujący na peryferiach kultury, z dala od centrum zjawisk semiotycznych. Najbardziej "gorącymi” miejscami procesów semiozy są granice semiosfery. Tu w binarnych czy też polingwistycznych obszarach dokonuje się przekład cudzej semiotyki na nasze rozumienie znaczeń. Dokonuje się tu również transformacja i przyswojenie tego, co obce, na to, co nasze. Aby kontakty międzykulturowe były możliwe, tworzy się obrazy-ekwiwalenty obcej kultury, które w naszej kulturze są przekładami umożliwiającymi pełne zrozumienie sensu przekazu; mogą one jednak stanowić też przeszkodę i fałszować informację. Granica oddzielająca wewnętrzną przestrzeń semiosfery od zewnętrznej jest podziałem pierwotnym. W istocie cała przestrzeń semiosfery jest poprzecinana granicami różnych poziomów, języków, tekstów, idei, sposobów życia. Poprzecinanie semiosfery licznymi granicami stwarza dla każdego komunikatu sytuację wielokrotnych przekładów, co znowu może sprzyjać transformacji lub zakłócać znaczenia. Łotman, definiując język naturalny, wtórne systemy modelujące, przestrzeń semiotyczną, granicę semiozy, centrum i peryferia przestrzeni symbolicznej, stworzył ogólną teorię kultury, będącą wielopoziomową metaforą.

8 Ibidem, s. 20. 


\section{Metoda semiotyczna a pogranicza}

Ten ogólny model umożliwia wykorzystanie go w kulturowych badaniach pograniczy. Semiotyczna teoria kultury szkoły tartusko-moskiewskiej nie ogranicza się wyłącznie do egzemplifikacji związanej z twórczością artystyczną. Znajdują się w niej odwołania do nauki jako takiej, w tym socjologii. Łotman lokuje semiozę w centrum dziejącej się najogólniej kultury. Na to centrum składają się: język naturalny, będący podstawą, i nadbudowane nad nim wtórne systemy modelujące. Język nauki nie może obejść się bez podstawy, jaką jest język naturalny. Przekształcenie języka naturalnego w poziomy meta wymusza wszelka zorganizowana działalność ludzka.

Pogranicza są obszarem dużego nasilenia zjawisk semiotycznych. Są to peryferia, które w szczególny sposób wzbudzają zainteresowanie w centrum kultury, kierując uwagę na procesy społeczne, gospodarcze i kulturowe, odmienne niż w centrum. W Unii Europejskiej są to euroregiony, uprzywilejowane strefy gospodarcze, dysponujące dotacjami przeznaczonymi na wyrównanie różnic, co jest widoczne szczególnie na pograniczu polsko-niemieckim.

Granica jest źródłem przepływu różnorodnych tekstów kultury: komunikatów, znaczeń, symboli, języków, idei, wzorców zachowań, które mogą być przez społeczności przygraniczne przyswajane lub odrzucane, przekształcane i zmieniane. Ciągły dialog może być źródłem zarówno innowacji, jak i konfliktów społecznych. O mieszkańcu pogranicza Zbigniew Kurcz pisze, że jest specyficznym wytworem dynamicznych sił, oddziałujących na granicach państw narodowych. Powodują one większą wrażliwość i wyczucie na specyfikę działań ludzi po drugiej stronie granicy. Pobudzają do naśladownictwa lub powodują odrzucenie, w zależności od stopnia pozytywnego czy też negatywnego nastawienia do gospodarczych lub intelektualnych osiągnięć sąsiadów ${ }^{9}$. Całe to spektrum zachowań rozszerza horyzonty poznawcze mieszkańców pogranicza. Procesy te można badać z punktu widzenia semiotyki kultury, która jest nastawiona na dogłębną interpretację sensów czy też znaczeń obserwowanych zjawisk i tekstów kultury.

Polskie pogranicza $w$ procesie przemian (t. 1-4) pod redakcją Kurcza są rozległą panoramą dynamicznych procesów konstruowanych m.in. przez politykę UE i państwa narodowe. Nie ograniczają się one do sfery gospodarczej i społecznej, obejmują swoim zakresem przejawy zmian kulturowych. Semiotyka kultury może badać znaczenia i sensy tych zmian. W artykule Kurcza pt. Europeizacja i nacjonalizacja pograniczy ${ }^{10}$, zawartym $\mathrm{w}$ tomie trzecim przytoczonej publikacji, znajduje się zupełnie nowe spojrzenie na funkcjonowanie granic w UE. Te dwa

9 Z. Kurcz, Przedmiot socjologii pogranicza w świetle polskich doświadczeń, [w:] Polskie pogranicza w procesie przemian, red. idem, t. 1, Wałbrzych 2008, s. 13.

10 Z. Kurcz, Europeizacja i nacjonalizacja pograniczy, [w:] Pogranicza w procesie przemian, red. idem, t. 3, Wrocław 2014, s. 38. 
terminy - „europeizacja pograniczy” $i$ „nacjonalizacja pograniczy” - funkcjonują w odmiennych przestrzeniach semiotycznych, wyznaczonych przez współczesną rzeczywistość polityczną i społeczną. Granica między nimi jest wyrazista i trudna do przekroczenia. Europeizacja jest tworem idealnym, który „proponuje ład oparty na równości i eliminacji wszelkiego podporządkowania, sięgając do idei Roberta Szumana"11. Nacjonalizacja natomiast oznacza „trwanie tradycyjnej rywalizacji, która rozstrzyga o dynamice stosunków pomiędzy narodami i państwami narodowymi” ${ }^{12}$. W tej rywalizacji stosunek nadrzędności i podrzędności między państwami narodowymi wynika z panowania silniejszego nad słabszym, bogatszego nad biedniejszym. Takie są rzeczywiste realia, a idee o sprawiedliwym podziale dóbr pozostają fikcją. Dlatego też Kurcz w kontekście ponadnarodowych, globalnych instytucji dbających o interesy najbogatszych wspomina o tych politykach RFN, którzy mówią, że Niemcy nie mogą jawnie formułować swoich interesów narodowych $\mathrm{w}$ imię poprawności politycznej i przynależności do UE, której szlachetne idee popierają, gdyż zaburzyłoby to sens funkcjonowania UE. Jest to stanowisko naznaczone dyplomatyczną poprawnością, ale za nim ukryta jest prawdziwa przemoc gospodarki niemieckiej.

Jednakże istnieje taka przestrzeń semiotyczna, w której stosunek nadrzędności i podrzędności ulega zatarciu. Jest to kultura w węższym rozumieniu. Działalność ludzi nauki i sztuki nie zna barier narodowych. Odkrycia naukowe oraz wybitne dzieła sztuki są wspólną wartością całej ludzkości. Imprezy sportowe i kulturalne, konferencje naukowe, publikacje dwujęzycznych tekstów dotyczących pograniczy integrują odrębne narodowo społeczności i przyczyniają się do dialogu, który mogą zaakceptować wszystkie zainteresowane nim strony.

Wielką rolę w integracji lub dezintegracji społeczeństw spełniają przepływy przez granice semiotyczne, w tym polityczne, różnorodnych idei, których krążenie zmienia czy też wpływa na rzeczywistość. W Polskich pograniczach $w$ procesie przemian (t. 3) znajdują one odzwierciedlenie w postaci adekwatnych terminów, nazywających znane wcześniej zjawiska, ulegające obecnie znacznym przekształceniom. Transgranicze ${ }^{13}$, europeizacja i nacjonalizacja pogranicza ${ }^{14}$, transnarodowość ${ }^{15}$ wskazują na procesy społeczne, mające miejsce po wejściu Polski do UE. Wszystkie te terminy, choć istniały wcześniej w języku naturalnym, w języku naukowym zyskały nowy sens, będący odbiciem procesów społecznych na pograniczach polskich i w centrum zjawisk kulturowych. Granice semiotyczne między europeizacją i nacjonalizacją, przebiegające w świadomości uczestników

11 Ibidem.

12 Ibidem, s. 34.

${ }^{13}$ H. Rusek, Czesko-polskie pogranicze na Śląsku Cieszyńskim po transformacji. Szkic socjologiczny, [w:] Polskie pogranicza..., t. 1, s. 53.

14 Z. Kurcz, Europeizacja i nacjonalizacja pograniczy, s. 39.

15 E. Opiłowska, Transnarodowość jako paradygmat badawczy w studiach nad pograniczem. Przyczynek do debaty, [w:] Polskie pogranicza..., t. 1, s. 34. 
tych procesów, wyraźnie wytyczone przez sprzeczne siły czy też interesy państw narodowych i organizacji ponadnarodowych, np. UE, są silnie odczuwane przez społeczeństwa.

Ochrona tożsamości narodowej wydaje się skrajnym ruchom i organizacjom nacjonalistycznym niezbędna po obu stronach granicy polsko-niemieckiej. Często protesty tych grup, niezadowolonych $\mathrm{z}$ aktualnego kierunku polityki państwowej, przejawiają się w nawiązaniu do haseł nazistowskich. Tym samym całkowicie zaprzeczają idei pokojowego współistnienia narodów, głoszonego przez prekursora UE - Szumana. Granica semiotyczna między europeizacją a nacjonalizacją jest dla ruchów i grup skrajnie nacjonalistycznych nie do pokonania. Dysonans między ideą gospodarczego i politycznego wspótistnienia narodów a ideą dominowania i panowania bogatych nad biednymi narodami jest tu realną granicą. A znaki, symbole (flaga UE, nazistowski krzyż) i idee polityczne są komunikatami lub tekstami kultury, objaśniającymi sens albo znaczenie prawd głoszonych przez eurosceptyków, neonazistów czy też zwolenników UE. Argumentacja umiarkowanych przeciwników UE przybiera różne formy — od artykułów prasowych, przez wykorzystywanie przekazów telewizyjnych i internetowych, do protestów ulicznych.

Nurty antyeuropejskie o charakterze fundamentalistycznym nie mają możliwości zaistnienia w oficjalnych mediach, ich zwolennicy protestują zatem na ulicach wielkich miast w sposób daleki od przyjętych norm zachowania w miejscach publicznych. Jest to nie-kultura funkcjonująca na peryferiach przestrzeni semiotycznej, nieakceptowana w centrum przestrzeni semiotycznej, która - jak wiemy - jest wielością komunikatów i zorganizowanych tekstów poprzecinanych wieloma granicami niedostępnymi dla ekstremizmów.

\section{Metoda semiotyczna a cywilizacja islamska i chrześcijańska}

Metoda semiotyczna w ujęciu Łotmana w istotny sposób koreluje ze zjawiskami mającymi miejsce na granicach cywilizacji. Zderzenie cywilizacji na granicach realnych i symbolicznych oraz jego skutki, obserwowane przez naukę w kształcie najbardziej ogólnym, pozwalają na wyciągnięcie ciekawych wniosków teoretycznych, mających charakter zarówno optymistyczny, jak i pesymistyczny.

W kontekście zupełnie nowych zjawisk socjologicznych, związanych z falą emigracji z Afryki i Azji do Europy, warto zapoznać się z artykułem Zdzisława Zagórskiego ${ }^{16}$, rozpatrującym problemy dominacji i przepływów informacji między cywilizacjami, związanymi z wartościami, jakie są im właściwe. Granice cywilizacji arabskiej zdominowanej przez islam i cywilizacji europejskiej, czyli

16 Z. Zagórski, Problem granic międzycywilizacyjnych we wspótczesnym świecie, [w:] Polskie pogranicza w procesie przemian, red. Z. Kurcz, t. 2, Wałbrzych 2011; por. J. Skoczyński, Koneczny, Teoria cywilizacji, Warszawa 2003, s. 168; F. Znaniecki, Studia nad antagonizmem do obcych, [w:] idem, Wspótczesne narody, Warszawa 1999. 
łacińskiej - w ujęciu Feliksa Konecznego - na naszych oczach ulegają przemieszczeniom ${ }^{17}$. Powstają enklawy zwane przez Zagórskiego bytami hybrydowymi, których w Europie, szczególnie zachodniej, jest coraz więcej w wielkich aglomeracjach miejskich, gdzie wyznawcy islamu kierują się prawem szariatu, a równocześnie korzystają z przywilejów obywatelskich cywilizacji łacińskiej. Granice między cywilizacjami zbliżyły się do nas i jesteśmy świadkami prób ich zacierania zgodnie z ideami pokojowego wspólistnienia świata wielokulturowego. Jest to zadanie trudne, być może niemożliwe do realizacji, a obserwacja zachowań ekstremistów arabskich i grup terrorystycznych z tzw. Państwa Islamskiego, wrogiego wartościom kultury chrześcijańskiej, zaprzecza pokojowej wizji współistnienia tak odmiennych cywilizacji. Granice państw narodowych UE, w porównaniu z granicami mentalnymi przybyszów z Afryki, są dla nich łatwiejsze do przekroczenia. Bariery kulturowe dzielące przestrzenie semiotyczne cywilizacji arabskiej i łacińskiej są oparte na odmiennych wartościach. Wartości cywilizacji zachodniej mieszczą się w takich aksjomatach, jak: „wolność, własność prywatna, rynek, indywidualizm, konkurencja, zasada racji większości i wyprowadzana $\mathrm{z}$ tej zasady sprawiedliwość społeczna"18 oraz - według Konecznego - ogólniejszych pryncypiach duchowych, takich jak dobro i prawda, i materialnych, takich jak zdrowie i dobrobyt, połączone kategorią piękna ${ }^{19}$.

Istnienie nierówności w cywilizacji zachodniej jest źródłem jej dynamiki, sprzyjającej rozwojowi w sferze gospodarczej i kulturowej. Stąd bierze się jej obecna przewaga nad cywilizacją arabską, ogarniętą fanatyzmem religijnym, gospodarczą zapaścią i wojnami, z wyjątkiem monarchii Saudów i bogatych emiratów arabskich, a także kryzysem politycznym, spowodowanym dysproporcją między archaicznym światopoglądem wywiedzionym z Koranu a nowoczesną nauką i osiągnięciami techniki oraz gospodarki zachodniej. Cywilizacja arabska, niegdyś dominująca, obecnie przeżywa upadek, z którego niektórzy islamscy przywódcy duchowi widzą wyjście poprzez konfrontację z Zachodem. Arabowie poszukują lepszych warunków życia w Europie, ale z trudem przystosowują się do warunków życia w cywilizacji europejskiej, a w rzeczywistości w większości przypadków wcale to nie jest ich celem. Prawa jednostki i wolności obywatelskie ogólnie obowiązujące w demokratycznej Europie w cywilizacji arabskiej nie istnieją. Wyżej ceniony jest tu interes i prawa grupy, a religia spełnia funkcje nie tyko rytualne, lecz porządkuje rygorystycznie całe życie społeczności, łącznie ze sprawowaniem władzy państwowej. Prawo rodzinne dopuszcza poligamię i utrzymuje uprzywilejowaną pozycję mężczyzn w rozstrzyganiu sporów małżeńskich. O rozwodzie decyduje mężczyzna, a kobiety są pozbawione tego prawa. Dostrzega się niedostatek prawa publicznego i stąd bierze się akceptacja władzy absolutnej, której

17 J. Skoczyński, op. cit., s. 25.

18 Z. Zagórski, op. cit., s. 11.

19 Ibidem, s. 25; J. Skoczyński, op. cit., s. 58. 
prawną podstawą jest Koran ${ }^{20}$. Relatywizm moralny cywilizacji zachodniej vs surowe przestrzeganie zasad moralnych i społecznych, dla których podstawą jest Koran, w cywilizacji arabskiej nakreśla nieprzekraczalną granicę semiotyczną między wolnością jednostek a jej ograniczaniem. Jest to oczywiście uproszczenie, ale pozwala uchwycić różnicę postaw jednostek wobec nakazów i zakazów obyczajowych oraz religijnych. Skrajne ugrupowania islamistyczne budują na tym rozróżnieniu wrogie ideologie, potępiające „krzyżowców”.

Zupełnie inaczej odbywa się komunikacja i dialog społeczeństw na granicach państw narodowych w Europie, w strefie Schengen i poza nią, gdyż są one połączone wspólnymi wartościami cywilizacji łacińskiej. Tu była możliwa nawet unia państw narodowych, czyli instytucjonalne respektowanie ekonomicznych i ideologicznych wartości UE. Wspólne wartości, z przestrzeganiem praw człowieka włącznie, zapewniają bezpieczeństwo jednostek, co przekłada się na zaufanie wobec sąsiadów na granicach i umożliwia kontakty międzynarodowe w różnych obszarach życia gospodarczego oraz kulturalnego. Rzeczywiste kontakty między narodami na pograniczach obecnie są silniejsze. Mają one różne oblicza, o czym informują autorzy artykułów zamieszczonych w czterech tomach Polskich pograniczy w procesie przemian. Wspólną ideą wyznaczającą kierunki życia na pograniczach jest dążenie do wyrównywania szans, kontaktów międzyludzkich, prowadzenia działalności gospodarczej, wymiany myśli o niepowodzeniach polityki UE i sposobach jej naprawienia. Potrzeba dominacji bogatych państw w UE jest konsekwencją ich siły militarnej i gospodarczej. Nie jest to jednak zawłaszczanie terytoriów krajów biedniejszych ani kontrolowanie ich polityki narodowej, lecz dążenie do pokojowego współistnienia. Jest to szczególnie ważne w czasach islamskiego zagrożenia terrorystycznego.

Fanatyzm i relatywizm, w całym swym obszarze znaczeniowym, wydają się tu istotnymi kategoriami, opisującymi zjawiska, jakie zachodzą w świecie zachodnim, tym bardziej że ulokowane są w cywilizacyjnym kontekście. Samuel P. Huntington stwierdza (podobnego zdania jest Koneczny), że cywilizacje są organizmami kulturowymi, a nie politycznymi. Na jedną cywilizację może się składać kilka państw lub jednostek politycznych ${ }^{21}$. Dla Zachodu problem stanowi nie islamski fundamentalizm, lecz islam będący religią cywilizacji arabskiej, której wyznawcy są przekonani o wyższości swojej kultury nad kulturą Zachodu, dlatego też czują się w obowiązku szerzyć ją na całym świecie ${ }^{22}$. Te idee wykorzystują terroryści islamscy, podsycając konflikt między islamem a chrześcijańskim Zachodem. Terroryści islamscy jako fanatyczni wyznawcy Allaha zdolni są do popełniania zbrodni potępianych przez cały cywilizowany świat, nawet

20 J. Bielawski, Komentarz, [w:] Koran, Warszawa 1986, s. 741; M. Goudefroy-Demombynes, Narodziny islamu, przeł. H. Olędzka, Warszawa 1988, s. 350.

21 S.P. Huntington, Zderzenie cywilizacji, przeł. H. Jankowska, Warszawa 2007, s. 53.

22 Ibidem, s. 372. 
przez współbraci w wierze. Relatywizm kultury zachodniej przeciwstawia się fundamentalizmowi arabskiemu, gdyż ceni sobie wolność jednostki w wielu wymiarach. W kulturze Zachodu współistnieją w zgodzie wyznawcy wielu religii, a Zachód jest jedynym miejscem, gdzie szanowane są wolność i godność jednostki, rządy prawa, demokracja polityczna, wolność kultury. To właśnie te wartości przesądzają o atrakcyjności cywilizacji Zachodu; są one pożądane przez swoją wyjątkowość, a nie uniwersalizm ${ }^{23}$. Cywilizacje: chińska, turańska, arabska nie znają pojęcia praw jednostki. Tylko dzięki ekspansji kultury Zachodu znalazły się one w kręgu zainteresowania religijnych ugrupowań arabskich, gdyż są zagrożeniem dla ustrojów absolutystycznych.

Granice znaczeniowe między fanatyzmem i fundamentalizmem a wolnością jednostki z przynależnymi jej prawami i wielokulturowością oraz relatywizmem w społecznej przestrzeni semiotycznej wydają się stanowić granice między kulturą a nie-kulturą. Nie-kultura wdziera się do centrum przestrzeni semiotycznej cywilizacji zachodniej, by narzucić swój punkt widzenia, by uczynić swoje racje nadrzędnymi.

\section{Wnioski}

Metodę semiotyczną szkoły tartusko-moskiewskiej można porównać z metodą hermeneutyczną, mającą zastosowanie w filozofiii ${ }^{24}$. Są to dwie równoległe wizje badawcze tekstów kultury. Obie zakładają historyczną interpretację procesów kulturowych, uwzględniają znaczenie teorii komunikacji dla rozumienia sensów komunikatów, przyznają znaczenie symboliczności i znakowości kultury. Interpretacja tekstów kultury, pojętych jako wszelkie komunikaty kulturowe, wyrażana przez szkołę tartusko-moskiewską wydaje się jednak mieć ogólniejszą formę niż metoda hermeneutyczna, gdyż podlega powiązaniom z semiosferą, rozumianą jako całość kultury ludzkiej, natomiast filozoficzna metoda hermeneutyczna skupiona jest głównie na samym tekście - dziele literackim, naukowym itp. Jest to ograniczenie, które czyni hermeneutyczną metodę filozoficzną zbyt wąską dla badań socjologicznych, wykorzystujących w badaniach ilościowych metodę statystyczną.

W niniejszym artykule zwrócono uwagę na niektóre aktualne zjawiska społeczne mające miejsce na pograniczach politycznych i kulturowych. Pogranicza polityczne zdominowane są głównie przez zainteresowanie sferą gospodarczą, w tym kontaktami nakierowanymi na wymianę gospodarczą towarów i usług między mieszkańcami terenów przygranicznych. Wymiana ta oprócz ekonomicznego ma wymiar komunikacyjny, gdyż wymusza znajomość języka sąsiadów. Z drugiej strony europeizacja pograniczy powoduje, że mieszkańcy zaczynają się interesować

23 Ibidem, s. 550.

24 A. Przyłębski, Hermeneutyczny zwrot filozofii, Poznań 2011; N. Leśniewski, O hermeneutyce radykalnej, Poznań 1998; A. Bronk, Rozumienie, dzieje, język, Lublin 1988. 
historią, obyczajami, polityką, kulturą sąsiadów, znajdują podobieństwa i różnice w tradycji i obyczajach. Porównania te nie zawsze są korzystne, bywa, że są krytyczne wobec mieszkańców po przeciwnej stronie granicy.

Metoda semiotyczna uwzględnia w interpretacji faktów kulturowych komunikaty tekstowe i nietekstowe. Obserwacja i analiza zjawisk na granicach semiozy, gdzie stykają się peryferia kulturowe z centrum kultury, wskazuje na ich dynamikę, polegającą na zderzeniu i wymianie sensów i znaczeń oraz na ich wpływie na rzeczywistość społeczną. Wspomniana $\mathrm{w}$ artykule europeizacja i nacjonalizacja to dwa zjawiska polityczne o przeciwstawnych sensach, ilustrujących komunikaty wysyłane przez sprzeczne z sobą siły polityczne. Kontekst historyczny nacjonalizacji jest związany $\mathrm{z}$ doświadczeniem państw narodowych i wynika $\mathrm{z}$ ich interesów politycznych. Kontekst ten łączy się z dziewiętnastowiecznym mitem państw narodowych o bezwzględnej niezależności i suwerenności. Europeizacja natomiast jest współczesnym trendem politycznym, głoszącym pogląd o wpływie gospodarki i kultury UE na kraje spoza niej. Głosi też idee i hasła pokojowego współistnienia narodów o odmiennych kulturach. Jednak współczesna rzeczywistość polityczna wskazuje na trudności w realizacji tej szlachetnej koncepcji współistnienia państw narodowych. Europeizacja wydaje się pojęciem idealnym, szczególnie w kontekście napływu emigrantów z Afryki północnej i Azji, którzy zderzając się z cywilizacją Zachodu, nie umieją się w niej odnaleźć, gdyż jej nie rozumieją. Komunikaty, jakie są im dostarczane przez media, informują o materialnym dobrobycie mieszkańców UE, ale nie informują o podstawowych prawach i obowiązkach oraz obyczajach i tradycji kulturowej. Nie uczą szacunku dla odmienności cywilizacyjnej chrześcijańskiego świata zachodniego. Wynika to $\mathrm{z}$ niedostatecznej komunikacji - barierą jest nieznajomość języka przez przybyszów, brak wykształcenia i opór wobec wartości kultury UE. Przybywają do Europy w wielkich grupach, które zaspokajają ich potrzeby kontaktów międzyludzkich i nie integrują się ze społeczeństwem europejskim. Nie respektują prawa europejskiego, postępują według zasad współistnienia społecznego w dzielnicach miast, będących diasporami islamskimi. Lepiej wykształceni obcokrajowcy mają szanse zdobyć dobrą pracę i zintegrować się ze społeczeństwem europejskim. Emigranci powinni mieć możliwość kształcenia się i zdobywania atrakcyjnych zawodów, by zacierały się różnice ekonomiczne między nimi a Europejczykami.

Wymienione problemy związane $\mathrm{z}$ asymilacją obcokrajowców wskazują na ogrom pracy, jaką należy wykonać, aby zintegrować ich ze społeczeństwem europejskim. Emigranci powinni jednak wykazać chęć współpracy, ucząc się języka i kultury kraju, do którego przybywają i w którym chcą zamieszkać. Komunikacja między nimi a nami jest niezbędnym warunkiem zrozumienia i porozumienia ${ }^{25}$.

25 Szerzej na temat roli kompetencji komunikacyjnych w rozumieniu podstawowych praw społecznych oraz fizycznych zob. B. Dyczek, Relacje między teoria a empiria w socjologii. Kontekst komunikacyjny, [w:] Komunikacja społeczna w perspektywie socjologicznej, red. J. Żurko, Wrocław 2013. 
Będzie to możliwe, gdy spełnione zostaną podstawowe warunki dla zrozumienia nadawcy i odbiorcy komunikatów. Choć całkowita identyfikacja z definicji jest niemożliwa, to jednak w podstawowych sprawach można się porozumieć.

\section{Bibliografia}

Bielawski J., Komentarz, [w:] Koran, Warszawa 1986.

Bronk A., Rozumienie, dzieje, język, Lublin 1988.

Dyczek B., Relacje między teoria a empiriq w socjologii. Kontekst komunikacyjny, [w:] Komunikacja społeczna w perspektywie socjologicznej, red. J. Żurko, Wrocław 2013.

Goudefroy-Demombynes M., Narodziny islamu, przeł. H. Olędzka, Warszawa 1988.

Huntington S.P., Zderzenie cywilizacji, przeł. H. Jankowska, Warszawa 2004.

Kurcz Z., Europeizacja i nacjonalizacja pograniczy, [w:] Polskie pogranicza w procesie przemian, red. Z. Kurcz, t. 3, Wrocław 2014.

Kurcz Z., Przedmiot socjologii pogranicza w świetle polskich doświadczeń, [w:] Polskie pogranicza w procesie przemian, red. Z. Kurcz, t. 1, Wrocław 2014.

Leśniewski N., O hermeneutyce radykalnej, Poznań 1998.

Łotman J., Uniwersum umysłu. Semiotyczna teoria kultury, przeł. B. Żyłko, Gdańsk 2008.

Michalski K., Heidegger i filozofia współczesna, Warszawa 1987.

Opiłowska E., Transnarodowość jako paradygmat badawczy w studiach nad pograniczem. Przyczynek do debaty, [w:] Pogranicza w procesie przemian, red. Z. Kurcz, t. 3, Wrocław 2014.

Przyłębski A., Hermeneutyczny zwrot filozofii, Poznań 2005.

Rusek H., Czesko-polskie pogranicze na Ślasku Cieszyńskim po transformacji. Szkic socjologiczny, [w:] Polskie pogranicza w procesie przemian, red. Z. Kurcz, t. 3, Wrocław 2014.

Skoczyński J., Koneczny. Teoria cywilizacji, Warszawa 2003.

Zagórski Z., Problem granic międzycywilizacyjnych we współczesnym świecie, [w:] Polskie pogranicza w procesie przemian, red. Z. Kurcz, t. 2, Wałbrzych 2011.

Znaniecki F., Studia nas antagonizmem do obcych, [w:] idem, Współczesne narody, Warszawa 1999.

Zuber M., Wizja komunikacji jako dyscypliny autonomicznej w koncepcji W. Barnetta Pearceaa „Prace z Antropologii Komunikacji i Epistemologii Społecznej” 2012, nr 1.

Żyłko B., Semiotyka kultury. Szkoła tartusko-moskiewska, Gdańsk 2009. 